\title{
Ultrasensitive Detection of Plasma Amyloid- $\beta$ as a Biomarker for Cognitively Normal Elderly Individuals at Risk of Alzheimer's Disease
}

Pratishtha Chatterjee, Ph.D. ${ }^{\text {a,b }}$, Mitra Elmi, M.Res. ${ }^{a}$, Kathryn Goozee, MCN ${ }^{\text {a,b,c,d,e,f,g, }}$ Tejal Shah, Ph.D. ${ }^{a, b, f}$, Hamid R. Sohrabi, Ph.D. ${ }^{\text {a,be,f }}$, Cintia B. Dias ${ }^{a}$, Steve Pedrini, M.Sc. ${ }^{\text {b }}$, Kaikai Shen, Ph.D. ${ }^{\text {, }}$ Prita R. Asih, Ph.D. ${ }^{a}$, Preeti Dave, M.Sc. ${ }^{\text {a,d }}$, Kevin Taddei, B.Sc. ${ }^{\text {b,f }}$, Hugo Vanderstichele $^{\mathrm{i}}$, Henrik Zetterberg, M.D., Ph.D. ${ }^{\mathrm{j}, \mathrm{k}, \mathrm{l}, \mathrm{m}}$, Kaj Blennow, M.D., Ph.D. ${ }^{\mathrm{j}, \mathrm{k}}$, Ralph N. Martins, Ph.D.*a,b,c,e,f,g

* Corresponding author

a: Department of Biomedical Sciences, Macquarie University, North Ryde, NSW, Australia b: School of Medical Health and Sciences, Edith Cowan University, Joondalup, WA, Australia c: KaRa Institute of Neurological Disease, Sydney, Macquarie Park, Australia d: Anglicare, Sydney, Castle Hill, NSW, Australia

e: School of Psychiatry and Clinical Neurosciences, University of Western Australia, Crawley, WA, Australia

f: Australian Alzheimer Research Foundation, Nedlands, WA, Australia

g: The Cooperative Research Centre for Mental Health, Carlton South, Australia

h: Australian eHealth Research Centre, CSIRO, Floreat, Australia

$i$ : ADx NeuroSciences, Gent, Belgium

j: Department of Psychiatry and Neurochemistry, Institute of Neuroscience and Physiology, University of Gothenburg, Mölndal, Sweden

k: Clinical Neurochemistry Laboratory, Sahlgrenska University Hospital, Mölndal, Sweden l: Department of Neurodegenerative Disease, UCL Institute of Neurology, Queen Square, London, United Kingdom

m: UK Dementia Research Institute at UCL, London, United Kingdom

Running title: Plasma $\mathrm{A} \beta$ in at-risk $\mathrm{AD}$ individuals

Contact information of corresponding author: Professor Ralph N. Martins, School of Medical and Health Sciences, Edith Cowan University, Ralph \& Patricia Sarich Neuroscience Research Institute, 8 Verdun Street, Nedlands, WA 6009, Australia, email: r.martins@ecu.edu.au. Telephone: (61 8) 6304 5456; Facsimile: (61 8) 63045851. 


\begin{abstract}
Introduction: Plasma amyloid- $\beta(\mathrm{A} \beta)$ is being investigated as a surrogate marker for brain $\mathrm{A} \beta$ deposition.
\end{abstract}

Methods: Plasma $A \beta 40$ and $A \beta 42$ concentrations were measured using the ultrasensitive Single Molecule Array (Simoa) assay in 95 cognitively normal elderly individuals, wherein all participants underwent positron emission tomography (PET) to assess brain A $\beta$ deposition. Based on the standard uptake value ratios (SUVR) obtained from PET imaging, 32 participants were assessed to have low brain A $\beta$ load $(A \beta-$, SUVR<1.35) and 63 were assessed to have high brain $A \beta$ load $(A \beta+, S U V R \geq 1.35)$.

Results: Plasma $A \beta 42 / A \beta 40$ ratios were lower in the $A \beta+$ group compared to the $A \beta$ - group. Plasma $A \beta 40$ and $A \beta 42$ levels were not significantly altered between $A \beta$ - and $A \beta+$ groups, although a trend of higher plasma $A \beta 40$ was observed in the $A \beta+$ group. Additionally, plasma $\mathrm{A} \beta 42 / \mathrm{A} \beta 40$ ratios along with the $\mathrm{AD}$ risk factors, age and $A P O E \varepsilon 4$ status, resulted in an area under the receiver operating characteristic curve of $78 \%$ in distinguishing $A \beta+$ participants from $\mathrm{A} \beta$ - participants.

Conclusion: Observations from the current study indicate that plasma $A \beta$ ratios are a potential biomarker for brain $\mathrm{A} \beta$ deposition and therefore, for preclinical $\mathrm{AD}$, characterised by high brain $A \beta$ load, prior to cognitive impairment. However, more sensitive and clinically feasible plasma $A \beta$ measurement assays need to be developed to increase the accuracy of this potential Alzheimer's disease blood biomarker. 


\section{Introduction}

Alzheimer's disease (AD) is the most common form of dementia. Presently, more than 50 million people worldwide are living with dementia and this statistic is expected to rise to over 150 million by 2050 , if there is no medical breakthrough [1].

Given that the onset of aberrant amyloid- $\beta(\mathrm{A} \beta)$ deposition in the brain occurs about two decades prior to the manifestation of clinical symptoms $[2,3]$, brain $A \beta$ load measured using positron emission tomography (PET) serves as a gold standard biomarker for preclinical and clinical AD. Preclinical AD diagnosis employing the gold standard markers are facilitating the recruitment of participants for clinical trials investigating potential drugs within the preclinical phase of $\mathrm{AD}$, prior to extensive neuronal damage. Additionally, preclinical $\mathrm{AD}$ diagnosis may also encourage the implementation of protective lifestyle changes [4]. However, the uneconomical nature of PET makes its usage unfeasible for population wide screening and therefore, blood markers that reflect brain $\mathrm{A} \beta$ deposition are being investigated.

While several studies have investigated plasma $\mathrm{A} \beta$ in $\mathrm{AD}$ [5], two relatively recent studies reported that plasma $A \beta$ ratios are significantly different between individuals with low brain $A \beta$ load (A $\beta-)$ versus those with high brain $A \beta$ load $(A \beta+)[6,7]$. The study by Ovod and colleagues reported that plasma $A \beta 42 / A \beta 40$ ratios were lower in $A \beta+$ versus $A \beta$ - participants and distinguished between $A \beta+$ versus $A \beta$ - participants with approximately $88 \%$ accuracy [6]. Further, Nakamura and colleagues reported that plasma $A \beta 40 / A \beta 42$ ratios were higher in $A \beta+$ versus $A \beta$ - participants. Additionally, the composite scores they obtained from the amyloid precursor protein fragment, APP669-711, to $A \beta 1-42$ ratio and the $A \beta 1-40$ to $A \beta 1-42$ ratio predicted $A \beta+$ versus $A \beta$ - participants with approximately $90 \%$ accuracy [7]. However, both studies employed immunoprecipitation using monoclonal anti-A $\beta$ antibodies (HJ5.1, antiA $\beta 13-28$ [6] and 6E10, anti-A $\beta 1-16$ [7]) prior to a liquid chromatography coupled with massspectrometry approach which may be difficult to implement in most clinical settings. Additionally, both studies included participants with mild cognitive impairment and dementia in their $A \beta-$ and $A \beta+$ groups.

Fandos and colleagues measured plasma $A \beta$ in cognitively normal $A \beta+$ individuals compared to $A \beta$ - individuals, utilising an enzyme linked immunosorbent assay (employing monoclonal antibody $1 \mathrm{~F} 3$ specific to the $\mathrm{A} \beta \mathrm{N}$-terminal and polyclonal antibodies pAB002 and pAB031 
specific to the C-terminal end of $\mathrm{A} \beta 40$ or $\mathrm{A} \beta 42$ respectively) and observed lower plasma $A \beta 42 / A \beta 40$ ratios in the $A \beta+$ group [8]. Further, Verberk and colleagues utilised the Single Molecule Array (Simoa) technology and observed lower plasma $A \beta 42 / A \beta 40$ ratios in cognitively normal individuals with subjective cognitive decline (SCD; referring to selfreported decline in cognitive performance [9]) carrying aberrant brain A $\beta$ deposition (assessed by cerebrospinal A $\beta 4$ levels $\leq 813 \mathrm{pg} / \mathrm{ml}$ ) compared to cognitively normal individuals with SCD carrying normal brain $\mathrm{A} \beta$ deposition [10]. Janelidze et. al. also reported that plasma $A \beta 42 / A \beta 40$ ratios inversely correlated with brain $A \beta$ load (assessed via PET) in cognitively normal individuals with SCD [11] (Supplementary table 1).

The current study aimed to validate the above studies utilising the ultra-sensitive Simoa technique to investigate whether plasma $\mathrm{A} \beta 42 / \mathrm{A} \beta 40$ ratios are significantly different between $A \beta$ - cognitively normal participants compared to $A \beta+$ cognitively normal participants assessed by PET in the Kerr Anglican Retirement Village Initiative in Ageing Health (KARVIAH) cohort. Additionally, the current study also evaluated the potential of plasma $A \beta 42 / A \beta 40$ ratios in differentiating $A \beta$ - and $A \beta+$ participants.

\section{Methods}

\section{Participants}

Study participants were from the KARVIAH cohort, at baseline. All cohort volunteers $(\mathrm{N}=206)$ were screened for the inclusion and exclusion criteria to be eligible. The inclusion criteria comprised an age range of 65-90 years, good general health, no known significant cerebral vascular disease, fluent in English, adequate/corrected vision and hearing to enable testing, and no objective cognitive impairment as screened by a Montreal Cognitive Assessment (MoCA) score $\geq 26$. MoCA scores lying between 18-25 were assessed on a case by case basis by the study neuropsychologist following stratification of scores according to age and education [12]. The exclusion criteria comprised, the diagnosis of dementia based on the revised criteria from the National Institute on Aging - Alzheimer's Association [13], presence of acute functional psychiatric disorder (including lifetime history of schizophrenia or bipolar disorder), history of stroke, severe or extremely severe depression (based on the depression, anxiety, stress scales; DASS) and uncontrolled hypertension (systolic BP > $170 \mathrm{~mm} \mathrm{Hg}$ or diastolic BP > $100 \mathrm{~mm}$ $\mathrm{Hg})$. 
While 134 volunteers met the inclusion/exclusion criteria, 105 participants underwent neuroimaging, neuropsychometric evaluation and blood collection since the remaining participants declined undergoing neuroimaging or withdrew from the study. Within these 105 participants, 100 participants were considered to have normal global cognition based on their Mini-Mental State Examination score [14] (MMSE $\geq 26$ ). Both plasma $A \beta 40$ and $A \beta 42$ concentrations were measured in 95 of these 100 participants. Additionally, participants with a Memory Assessment Clinic - Questionnaire (MAC-Q) score between 25-35 were considered as subjective memory complainers (SMC, $n=72$; a specific form of SCD defined by selfreported memory complaints) while those with a MAC-Q score $\leq 24$ were considered as noncomplainers $(n=23)$ (See Figure 1 for flowchart). All volunteers provided written informed consent prior to participation, and the Bellberry Human Research Ethics Committee, Australia, and the Macquarie University Human Research Ethics Committee provided approval for the study.

\section{Evaluation of neocortical amyloid- $\beta$ load via PET}

All study participants were imaged within three months of blood collection wherein participants underwent PET using ligand ${ }^{18}$ F-Florbetaben (FBB) at Macquarie Medical Imaging in Sydney. Participants were administered an intravenous bolus of FBB slowly over 30 s, while in a rested position. Images were acquired over a 20 min scan, in 5 min acquisitions, beginning 50 min post injection. Brain (neocortical) amyloid- $\beta$ load was calculated as the mean standard uptake value ratio (SUVR) of the frontal, superior parietal, lateral temporal, lateral occipital, and anterior and posterior cingulate regions using the image processing software, CapAIBL $[15,16]$ to classify participants as A $\beta$ - or A $\beta+$ using an SUVR cut-off $=1.35$ [17] within the current study.

\section{Blood collection, measurement of plasma Aß and APOE genotyping}

All study participants fasted for a minimum of 10 hours overnight prior to blood withdraw employing standard serological methods and processing [17]. EDTA-plasma A $\beta$ concentrations were measured employing the ultra-sensitive Single Molecule Array (Simoa, Quanterix) platform. Plasma samples were diluted eight times for $A \beta 40$ and four times for $A \beta 42$. For $A \beta 40$, the quality control (QC) sample had a concentration of $219 \mathrm{pg} / \mathrm{mL}$ with repeatability $6.9 \%$ and intermediate precision $7.9 \%$. For $\mathrm{A} \beta 42$, the QC sample had a concentration of $12.9 \mathrm{pg} / \mathrm{mL}$ with repeatability $2.4 \%$ and intermediate precision $5.6 \%$. 
Apolipoprotein E (APOE) genotype was determined from purified genomic DNA extracted from $0.5 \mathrm{ml}$ whole blood as previously described [17].

\section{Statistical analyses}

Descriptive statistics including means and standard deviations were calculated for $A \beta$ - and $A \beta+$ groups, with comparisons employing t-tests or Chi-square tests as appropriate. Linear models were employed to compare continuous variables between $A \beta$ - and $A \beta+$ groups corrected for covariates age, gender and $A P O E \& 4$ carrier status. Plasma $\mathrm{A} \beta$ concentrations and their ratios were $\log$ transformed to better approximate normality and variance homogeneity as required. Logistic regression with $A \beta-/+$ as response was used to evaluate predictive models and receiver operating characteristic (ROC) curves constructed from the logistic scores. All analyses were carried out using IBM $^{\circledR}$ SPSS $^{\circledR}$ Version 23 and receiver operating characteristic curves were generated using the package Deducer on $\mathrm{R}$ (version 3.2.5).

\section{Results}

\section{Cohort characteristics}

Demographic characteristics of study participants have been presented in Table 1. No significant differences were observed in gender, age, body mass index, MMSE scores and the number of SMC between $\mathrm{A} \beta$ - and $\mathrm{A} \beta+$ cohort participants. However, the APOE \&4 carriage frequency was significantly higher in the $A \beta+$ group compared to $A \beta$ - group as expected [18] (Table 1).

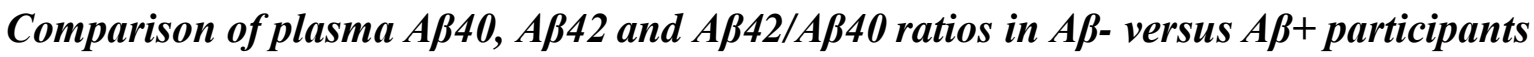

Plasma $A \beta 40$ and $A \beta 42$ concentrations and plasma $A \beta 42 / A \beta 40$ ratios, measured in the study participants have been presented in Table 2. While no significant differences were observed in plasma $A \beta 40$ and $A \beta 42$ concentrations between the $A \beta$ - and $A \beta+$ groups, significant differences in plasma $A \beta 42 / A \beta 40$ ratios were observed between the two groups, wherein $A \beta 42 / A \beta 40$ ratios were lower in the $A \beta+$ group compared to the $A \beta$ - group with and without correcting for covariates age, gender and $A P O E \varepsilon 4$ status (Figure 2).

On stratifying study participants into subjective memory complainers $(n=72)$ and noncomplainers $(n=23)$, plasma $A \beta 42 / A \beta 40$ ratios continued to remain significantly lower in the $\mathrm{A} \beta+\mathrm{SMC}$ compared to $\mathrm{A} \beta$ - SMC with and without correcting for covariates age, gender and 
$A P O E \& 4$ status (Table 2). However, no significant difference was observed in plasma $\mathrm{A} \beta 42 / \mathrm{A} \beta 40$ ratios between $\mathrm{A} \beta+$ and $\mathrm{A} \beta$ - non-SMC.

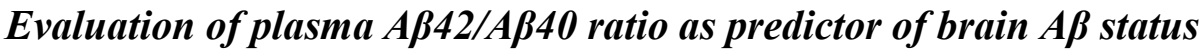

Plasma $A \beta 42 / A \beta 40$ ratios were evaluated as potential markers to predict $A \beta+$ status using logistic regression with $A \beta+/$ - as response. A 'base' model incorporating the major risk factors for $\mathrm{AD}$, namely age and $A P O E \& 4$ allele status, was generated and compared to the 'base+ $\mathrm{A} \beta 42 / \mathrm{A} \beta 40$ ratio' model wherein plasma $A \beta 42 / \mathrm{A} \beta 40$ ratios were added to the base model (Figure 3). The area under the curve (AUC) of the 'base+ $A \beta 42 / A \beta 40$ ratio' model $(\mathrm{AUC}=77.6 \%$, specificity $=67 \%$ at sensitivity $=78 \%, 95 \% \mathrm{CI}=68-88 \%)$ outperformed the 'base' model (AUC $=75.3 \%$, specificity $=56 \%$ at sensitivity $=78 \%, 95 \% \mathrm{CI}=65-86 \%)$ in distinguishing $\mathrm{A} \beta+$ from $A \beta$ - participants.

\section{Discussion}

The current study found that while plasma $A \beta 40$ and $A \beta 42$ concentrations were not significantly altered between $A \beta$ - and $A \beta+$ participants, the ratio of $A \beta 42 / A \beta 40$ was significantly lower in $\mathrm{A} \beta+$ participants compared to $\mathrm{A} \beta$ - participants. Further, on stratifying cohort participants into SMC and non-SMC, the ratio of $\mathrm{A} \beta 42 / \mathrm{A} \beta 40$ was significantly lower in $\mathrm{A} \beta+\mathrm{SMC}$ compared to $\mathrm{A} \beta$ - SMC. While the mean of the ratio of $\mathrm{A} \beta 42 / \mathrm{A} \beta 40$ was lower in $\mathrm{A} \beta+$ non-SMC compared to $\mathrm{A} \beta$ - non-SMC, it did not reach statistical significance, which could be due to the small sample size following stratification based on self-reported memory complaints. Further, plasma $\mathrm{A} \beta 42 / \mathrm{A} \beta 40$ ratios along with $\mathrm{AD}$ risk factors age and $A P O E \varepsilon 4$ status in all participants predicted $\mathrm{A} \beta+$ individuals with approximately $78 \%$ accuracy. Interestingly, Nakamura et al. employed A $\beta 40 / \mathrm{A} \beta 42$ ratios to predict individuals with aberrant brain $A \beta$ deposition while Ovod et al. employed $A \beta 42 / A \beta 40$ ratios. Within the current study we observed similar AUCs for both ratios (Supplementary figure 1, Supplementary figure 2) $[6,7]$.

Two relatively recent studies also investigated plasma $A \beta$ as a surrogate marker for abnormal brain $\mathrm{A} \beta$ deposition in cognitively normal individuals $[8,10]$. Fandos and colleagues measured plasma A $\beta$ levels using enzyme-linked immunosorbent assays (ELISA) (Araclon Biotech Ltd. Zaragoza, Spain) in individuals with normal and abnormal brain $\mathrm{A} \beta$ deposition classified by 
PET and reported that plasma $A \beta 42 / A \beta 40$ ratios were lower in individuals with abnormal brain $\mathrm{A} \beta$ deposition [8], which is in line with observations from the current study. Further, employing the ultra-sensitive Simoa assay (Quanterix) to measure plasma A $\beta$, Verberk and colleagues also observed significantly lower plasma $A \beta 42 / A \beta 40$ ratios in individuals with abnormal brain $A \beta$ deposition defined by cerebrospinal fluid (CSF) A $\beta 42$ levels ( $\leq 813 \mathrm{pg} / \mathrm{ml})[10]$.

Along with $\mathrm{AD}$ risk factors, age and $A P O E \varepsilon 4$ carriage, Fandos et al. reported an AUC of $79 \%$ and Verberk et al. reported an AUC of $83 \%$ in distinguishing between individuals with abnormal brain $\mathrm{A} \beta$ deposition and those with normal brain $\mathrm{A} \beta$ deposition [8, 10]. However, only a trend of lower plasma $A \beta 42 / A \beta 40$ ratios $(p=.057)$ was observed in individuals with abnormal brain $A \beta$ deposition $(n=23)$ defined by PET, in the subset of participants that underwent PET ( $\mathrm{n}=69)$ in the Verberk et al. study [10]. This observation could be attributed to the modest sample size of individuals who underwent PET and the multiple PET ligands employed in the study. Additionally, while the study by Fandos and colleagues accounted for employing multiple PET ligands using the "Before the Centiloid Kernel Transformation" $(\mathrm{BeCKeT})$ scale, they employed a plasma $\mathrm{A} \beta$ measurement assay with a relatively lower sensitivity (lower limit of quantification, LOQ; A $\beta 40: 7.60 \mathrm{pg} / \mathrm{ml}, \mathrm{A} \beta 42: 3.60 \mathrm{pg} / \mathrm{ml}$ ) [8, 19] compared to the Simoa assay used by Verberk and colleagues (LOQ; A $\beta 40: 0.16 \mathrm{pg} / \mathrm{ml}, \mathrm{A} \beta 42$ : $0.34 \mathrm{pg} / \mathrm{ml}$ ) [10]. The current study utilised the ultrasensitive Simoa assay, to measure plasma $\mathrm{A} \beta$ concentrations, along with PET data (using a single ligand), to identify individuals with abnormal brain $\mathrm{A} \beta$ deposition, and validated findings from the above two studies wherein plasma $A \beta 42 / A \beta 40$ ratios were lower in individuals at risk of $A D(A \beta+)$.

Several previous studies have investigated plasma $\mathrm{A} \beta$ in $\mathrm{AD}$, however findings have been inconsistent. For example, a number of studies reported that lower plasma A $\beta 42$ and higher plasma $\mathrm{A} \beta 40$ were associated with increased $\mathrm{AD}$ or dementia risk $[20,21]$ while other studies did not observe any association of plasma $A \beta 42$ or $A \beta 40$ with $A D$ [22, 23]. Further, several other studies also reported that lower plasma $A \beta 42 / A \beta 40$ ratios were significantly associated with increased AD risk [24-27] although other studies did not observe these associations [28, 29]. These inconsistencies could be attributed to poorly characterised cohorts, non-sensitive plasma $\mathrm{A} \beta$ assays, variations between study designs (fasting bloods, time of blood collection and processing time) and inadequate sample sizes. While the current study endeavoured to address these issues by employing a highly characterised cohort that has undergone PET to measure brain $A \beta$ deposition (with a single $A \beta$ specific ligand), an ultra-sensitive plasma $A \beta$ 
measurement assay and a sample collection and processing design similar that used by Fandos and colleagues [8], it is also acknowledged that the study has its limitations of employing a modest sample size and a cross-sectional study design.

To conclude, while our current observations together with those of Fandos et al. and Verberk et al. validate that plasma $\mathrm{A} \beta$ ratios $(\mathrm{A} \beta 42 / \mathrm{A} \beta 40)$ are altered in cognitively normal individuals with aberrant brain $A \beta$ deposition, the accuracy to identify aberrant brain $A \beta$ deposition attained by the methods employed to measure plasma $\mathrm{A} \beta$ ratios by Ovod et al. and Nakamura et al. makes plasma $\mathrm{A} \beta$ ratios a promising marker $[6-8,10]$. However, given that the assays employed by Ovod et al. and Nakamura et al. cannot readily be implemented in a clinical setting, more sensitive and clinically feasible assays to measure plasma $A \beta$ are still required to be developed $[6,7]$. 


\section{References}

[1] Dementia - Key facts,World Health Organisation, https://www.who.int/news-room/factsheets/detail/dementia, 2017,

[2] Villemagne VL, Burnham S, Bourgeat P, Brown B, Ellis KA, Salvado O, Szoeke C, Macaulay SL, Martins R, Maruff $P$, Ames D, Rowe CC, Masters CL, Australian Imaging B, Lifestyle Research $G$ (2013) Amyloid beta deposition, neurodegeneration, and cognitive decline in sporadic Alzheimer's disease: a prospective cohort study. Lancet Neurol 12, 357-367.

[3] Bateman RJ, Xiong C, Benzinger TL, Fagan AM, Goate A, Fox NC, Marcus DS, Cairns NJ, Xie X, Blazey TM, Holtzman DM, Santacruz A, Buckles V, Oliver A, Moulder K, Aisen PS, Ghetti B, Klunk WE, McDade E, Martins RN, Masters CL, Mayeux R, Ringman JM, Rossor MN, Schofield PR, Sperling RA, Salloway S, Morris JC (2012) Clinical and biomarker changes in dominantly inherited Alzheimer's disease. N Engl J Med 367, 795-804.

[4] Ngandu T, Lehtisalo J, Solomon A, Levalahti E, Ahtiluoto S, Antikainen R, Backman L, Hanninen T, Jula A, Laatikainen T, Lindstrom J, Mangialasche F, Paajanen T, Pajala S, Peltonen M, Rauramaa R, Stigsdotter-Neely A, Strandberg T, Tuomilehto J, Soininen $H$, Kivipelto M (2015) A 2 year multidomain intervention of diet, exercise, cognitive training, and vascular risk monitoring versus control to prevent cognitive decline in at-risk elderly people (FINGER): a randomised controlled trial. Lancet 385, 2255-2263.

[5] Song F, Poljak A, Valenzuela M, Mayeux R, Smythe GA, Sachdev PS (2011) Meta-analysis of plasma amyloid-beta levels in Alzheimer's disease. J Alzheimers Dis 26, 365-375.

[6] Ovod V, Ramsey KN, Mawuenyega KG, Bollinger JG, Hicks T, Schneider T, Sullivan M, Paumier K, Holtzman DM, Morris JC, Benzinger T, Fagan AM, Patterson BW, Bateman RJ (2017) Amyloid beta concentrations and stable isotope labeling kinetics of human plasma specific to central nervous system amyloidosis. Alzheimers Dement 13, 841-849.

[7] Nakamura A, Kaneko N, Villemagne VL, Kato T, Doecke J, Dore V, Fowler C, Li QX, Martins R, Rowe C, Tomita T, Matsuzaki K, Ishii K, Ishii K, Arahata Y, Iwamoto S, Ito K, Tanaka K, Masters $\mathrm{CL}$, Yanagisawa K (2018) High performance plasma amyloid-beta biomarkers for Alzheimer's disease. Nature 554, 249-254.

[8] Fandos N, Perez-Grijalba V, Pesini P, Olmos S, Bossa M, Villemagne VL, Doecke J, Fowler C, Masters CL, Sarasa M, Group AR (2017) Plasma amyloid beta 42/40 ratios as biomarkers for amyloid beta cerebral deposition in cognitively normal individuals. Alzheimers Dement (Amst) 8, 179-187.

[9] Jessen F, Amariglio RE, van Boxtel M, Breteler M, Ceccaldi M, Chetelat G, Dubois B, Dufouil C, Ellis KA, van der Flier WM, Glodzik L, van Harten AC, de Leon MJ, McHugh P, Mielke MM, Molinuevo JL, Mosconi L, Osorio RS, Perrotin A, Petersen RC, Rabin LA, Rami L, Reisberg B, Rentz DM, Sachdev PS, de la Sayette V, Saykin AJ, Scheltens P, Shulman MB, Slavin MJ, Sperling RA, Stewart R, Uspenskaya O, Vellas B, Visser PJ, Wagner M, Subjective Cognitive Decline Initiative Working $G$ (2014) A conceptual framework for research on subjective cognitive decline in preclinical Alzheimer's disease. Alzheimers Dement 10, 844-852.

[10] Verberk IMW, Slot RE, Verfaillie SCJ, Heijst H, Prins ND, van Berckel BNM, Scheltens P, Teunissen CE, van der Flier WM (2018) Plasma Amyloid as Prescreener for the Earliest Alzheimer Pathological Changes. Ann Neurol 84, 648-658.

[11] Janelidze S, Stomrud E, Palmqvist S, Zetterberg $H$, van Westen $D$, Jeromin A, Song L, Hanlon D, Tan Hehir CA, Baker D, Blennow K, Hansson O (2016) Plasma beta-amyloid in Alzheimer's disease and vascular disease. Sci Rep 6, 26801.

[12] Rossetti HC, Lacritz LH, Cullum CM, Weiner MF (2011) Normative data for the Montreal Cognitive Assessment (MoCA) in a population-based sample. Neurology 77, 1272-1275.

[13] McKhann GM, Knopman DS, Chertkow H, Hyman BT, Jack CR, Jr., Kawas CH, Klunk WE, Koroshetz WJ, Manly JJ, Mayeux R, Mohs RC, Morris JC, Rossor MN, Scheltens P, Carrillo MC, Thies B, Weintraub S, Phelps CH (2011) The diagnosis of dementia due to Alzheimer's 
disease: recommendations from the National Institute on Aging-Alzheimer's Association workgroups on diagnostic guidelines for Alzheimer's disease. Alzheimers Dement 7, 263-269.

[14] Folstein MF, Folstein SE, McHugh PR (1975) "Mini-mental state". A practical method for grading the cognitive state of patients for the clinician. J Psychiatr Res 12, 189-198.

[15] Zhou L, Salvado O, Dore V, Bourgeat P, Raniga P, Macaulay SL, Ames D, Masters CL, Ellis KA, Villemagne VL, Rowe CC, Fripp J, Group AR (2014) MR-less surface-based amyloid assessment based on 11C PiB PET. PLoS One 9, e84777.

[16] Bourgeat P, Villemagne VL, Dore V, Brown B, Macaulay SL, Martins R, Masters CL, Ames D, Ellis K, Rowe CC, Salvado O, Fripp J, Group AR (2015) Comparison of MR-less PiB SUVR quantification methods. Neurobiol Aging 36 Suppl 1, S159-166.

[17] Goozee K, Chatterjee P, James I, Shen K, Sohrabi HR, Asih PR, Dave P, ManYan C, Taddei K, Ayton SJ, Garg ML, Kwok JB, Bush Al, Chung R, Magnussen JS, Martins RN (2017) Elevated plasma ferritin in elderly individuals with high neocortical amyloid- $\beta$ load. Molecular Psychiatry.

[18] Polvikoski T, Sulkava R, Haltia M, Kainulainen K, Vuorio A, Verkkoniemi A, Niinisto L, Halonen P, Kontula K (1995) Apolipoprotein E, dementia, and cortical deposition of beta-amyloid protein. N Engl J Med 333, 1242-1247.

[19] Perez-Grijalba V, Fandos N, Canudas J, Insua D, Casabona D, Lacosta AM, Montanes M, Pesini $P$, Sarasa M (2016) Validation of Immunoassay-Based Tools for the Comprehensive Quantification of Abeta40 and Abeta42 Peptides in Plasma. J Alzheimers Dis 54, 751-762.

[20] Buerger K, Frisoni G, Uspenskaya O, Ewers M, Zetterberg H, Geroldi C, Binetti G, Johannsen P, Rossini PM, Wahlund LO, Vellas B, Blennow K, Hampel H (2009) Validation of Alzheimer's disease CSF and plasma biological markers: the multicentre reliability study of the pilot European Alzheimer's Disease Neuroimaging Initiative (E-ADNI). Exp Gerontol 44, 579-585.

[21] Pesaresi M, Lovati C, Bertora P, Mailland E, Galimberti D, Scarpini E, Quadri P, Forloni G, Mariani C (2006) Plasma levels of beta-amyloid (1-42) in Alzheimer's disease and mild cognitive impairment. Neurobiol Aging 27, 904-905.

[22] Giedraitis V, Sundelof J, Irizarry MC, Garevik N, Hyman BT, Wahlund LO, Ingelsson M, Lannfelt $L$ (2007) The normal equilibrium between CSF and plasma amyloid beta levels is disrupted in Alzheimer's disease. Neurosci Lett 427, 127-131.

[23] Tamaoka A, Fukushima T, Sawamura N, Ishikawa K, Oguni E, Komatsuzaki Y, Shoji S (1996) Amyloid beta protein in plasma from patients with sporadic Alzheimer's disease. J Neurol Sci 141, 65-68.

[24] van Oijen M, Hofman A, Soares HD, Koudstaal PJ, Breteler MM (2006) Plasma Abeta(1-40) and Abeta(1-42) and the risk of dementia: a prospective case-cohort study. Lancet Neurol 5, 655-660.

[25] Chouraki V, Beiser A, Younkin L, Preis SR, Weinstein G, Hansson O, Skoog I, Lambert JC, Au R, Launer L, Wolf PA, Younkin S, Seshadri S (2015) Plasma amyloid-beta and risk of Alzheimer's disease in the Framingham Heart Study. Alzheimers Dement 11, 249-257 e241.

[26] Abdullah L, Luis C, Paris D, Mouzon B, Ait-Ghezala G, Keegan AP, Wang D, Crawford F, Mullan $M(2009)$ Serum Abeta levels as predictors of conversion to mild cognitive impairment/Alzheimer disease in an ADAPT subcohort. Mol Med 15, 432-437.

[27] Graff-Radford NR, Crook JE, Lucas J, Boeve BF, Knopman DS, Ivnik RJ, Smith GE, Younkin LH, Petersen RC, Younkin SG (2007) Association of low plasma Abeta42/Abeta40 ratios with increased imminent risk for mild cognitive impairment and Alzheimer disease. Arch Neurol 64, 354-362.

[28] Hansson $\mathrm{O}$, Zetterberg $\mathrm{H}$, Vanmechelen $\mathrm{E}$, Vanderstichele $\mathrm{H}$, Andreasson $\mathrm{U}$, Londos $\mathrm{E}$, Wallin A, Minthon L, Blennow K (2010) Evaluation of plasma Abeta(40) and Abeta(42) as predictors of conversion to Alzheimer's disease in patients with mild cognitive impairment. Neurobiol Aging 31, 357-367. 
[29] Lovheim H, Elgh F, Johansson A, Zetterberg H, Blennow K, Hallmans G, Eriksson S (2017) Plasma concentrations of free amyloid beta cannot predict the development of Alzheimer's disease. Alzheimers Dement 13, 778-782. 


\section{Tables}

Table 1. Demographic characteristics of cohort participants. Baseline characteristics including gender, age, body mass index (BMI), $A P O E \varepsilon 4$ status, mini mental state examination (MMSE) scores, subjective memory complainer status and brain $A \beta$ load represented by the standard uptake value ratio (SUVR) of ligand ${ }^{18} \mathrm{~F}$-Florbetaben (FBB) in the neocortical region normalised with that in the cerebellum, have been compared between $A \beta$ - (SUVR $<1.35$ ) and $A \beta+(S U V R \geq 1.35)$ study participants. Chi-square tests or linear models were employed as appropriate.

\begin{tabular}{|l|l|l|l|}
\hline & $\mathbf{A} \boldsymbol{\beta}-$ & $\mathbf{A} \boldsymbol{\beta}+$ & $\mathbf{p}$ \\
\hline Gender (M/F) & $19 / 44$ & $13 / 19$ & .308 \\
\hline Age (years, mean \pm SD) & $77.65 \pm 5.62$ & $79.50 \pm 5.32$ & .126 \\
\hline BMI (mean \pm SD) & $27.54 \pm 4.46$ & $27.62 \pm 4.13$ & .931 \\
\hline nAPOE $\varepsilon 4$ carriers (\%) & $5(7.9)$ & $13(40.6)$ & $<.0001$ \\
\hline MMSE (mean \pm SD) & $28.51 \pm 1.15$ & $28.72 \pm 1.11$ & .395 \\
\hline Subjective memory complainers (n) & 49 & 23 & .526 \\
\hline FBB-PET SUVR (mean \pm SD) & $1.16 \pm 0.09$ & $1.73 \pm 0.27$ & - \\
\hline
\end{tabular}




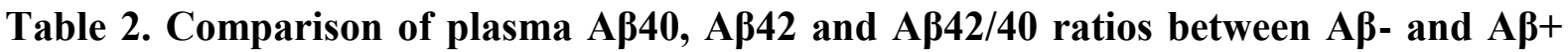
participants. Plasma $A \beta$ concentrations and their ratios were compared between cognitively normal individuals with low brain $A \beta$ load $(A \beta-)$ and high brain $A \beta$ load $(A \beta+)$ using linear models. All participants were further categorised into subjective memory complainers (SMC, $\mathrm{n}=72)$ and non-SMC $(\mathrm{n}=23) . \dagger$ represents $\mathrm{p}$-values obtained from log transformed plasma A $\beta$ concentrations and ratios to better approximate normality. $\mathrm{p}^{\mathrm{a}}$ represents $\mathrm{p}$-values adjusted for age, gender and $A P O E \& 4$ status.

\begin{tabular}{|c|c|c|c|c|c|c|}
\hline & $\mathbf{A} \boldsymbol{\beta}-$ & $(95 \% \mathrm{CI})$ & $\mathbf{A} \boldsymbol{\beta}+$ & $(95 \% \mathrm{CI})$ & p & $\mathbf{p}^{\mathbf{a}}$ \\
\hline All participants & $n=63$ & & $n=32$ & & & \\
\hline $\begin{array}{l}\mathrm{A} \beta 40(\mathrm{pg} / \mathrm{mL} \\
\text { mean } \pm \mathrm{SD})\end{array}$ & $307.44 \pm 54.16$ & $(292.08-322.79)$ & $332.82 \pm 73.71$ & $(311.28-354.37)$ & $.087 \dagger$ & .095 \\
\hline $\begin{array}{l}\mathrm{A} \beta 42(\mathrm{pg} / \mathrm{mL}, \\
\text { mean } \pm \mathrm{SD}))\end{array}$ & $16.01 \pm 3.74$ & $(15.09-16.92)$ & $15.71 \pm 3.48$ & $(14.43-17.00)$ & .711 & .741 \\
\hline $\begin{array}{l}\text { A } \beta 42 / 40 \text { ratio } \\
(\text { mean } \pm S D)\end{array}$ & $0.052 \pm .008$ & $(0.050-0.054)$ & $0.047 \pm 0.005$ & $(0.045-0.050)$ & $.004 \dagger$ & $.025 \dagger$ \\
\hline SMC & $\mathrm{n}=49$ & & $\mathrm{n}=\mathbf{2 3}$ & & & \\
\hline $\begin{array}{l}\mathrm{A} \beta 40(\mathrm{pg} / \mathrm{mL}, \\
\text { mean } \pm \mathrm{SD})\end{array}$ & $307.23 \pm 51.07$ & $(290.45-324.00)$ & $337.90 \pm 73.07$ & $(313.41-362.38)$ & .043 & .085 \\
\hline $\begin{array}{l}\mathrm{A} \beta 42(\mathrm{pg} / \mathrm{mL}, \\
\text { mean } \pm \mathrm{SD}))\end{array}$ & $15.80 \pm 3.26$ & $(14.86-16.75)$ & $15.69 \pm 3.42$ & $(14.32-17.07)$ & .898 & .990 \\
\hline $\begin{array}{l}\mathrm{A} \beta 42 / 40 \text { ratio } \\
(\mathrm{mean} \pm \mathrm{SD})\end{array}$ & $0.052 \pm .007$ & $(0.050-0.054)$ & $0.047 \pm 0.005$ & $(0.044-0.050)$ & .006 & .040 \\
\hline Non-SMC & $n=14$ & & $n=9$ & & & \\
\hline $\begin{array}{l}\mathrm{A} \beta 40(\mathrm{pg} / \mathrm{mL}, \\
\text { mean } \pm \mathrm{SD})\end{array}$ & $308.17 \pm 66.00$ & $(268.78-347.57)$ & $319.85 \pm 78.14$ & $(270.72-368.98)$ & .704 & .438 \\
\hline $\begin{array}{l}\mathrm{A} \beta 42(\mathrm{pg} / \mathrm{mL}, \\
\text { mean } \pm \mathrm{SD}))\end{array}$ & $16.74 \pm 5.17$ & $(14.12-19.36)$ & $15.77 \pm 3.83$ & $(12.51-19.03)$ & .635 & .835 \\
\hline $\begin{array}{l}\text { A } \beta 42 / 40 \text { ratio } \\
(\text { mean } \pm S D)\end{array}$ & $0.054 \pm .009$ & $(0.049-0.058)$ & $0.049 \pm 0.004$ & $(0.044-0.055)$ & .201 & .204 \\
\hline
\end{tabular}




\section{Figures}

Figure 1. Flow chart representing the Kerr Anglican Retirement Village Initiative in Ageing Health (KARVIAH) cohort participants included within the current study. MMSE: Mini-mental state examination score, SMC: subjective memory complainers

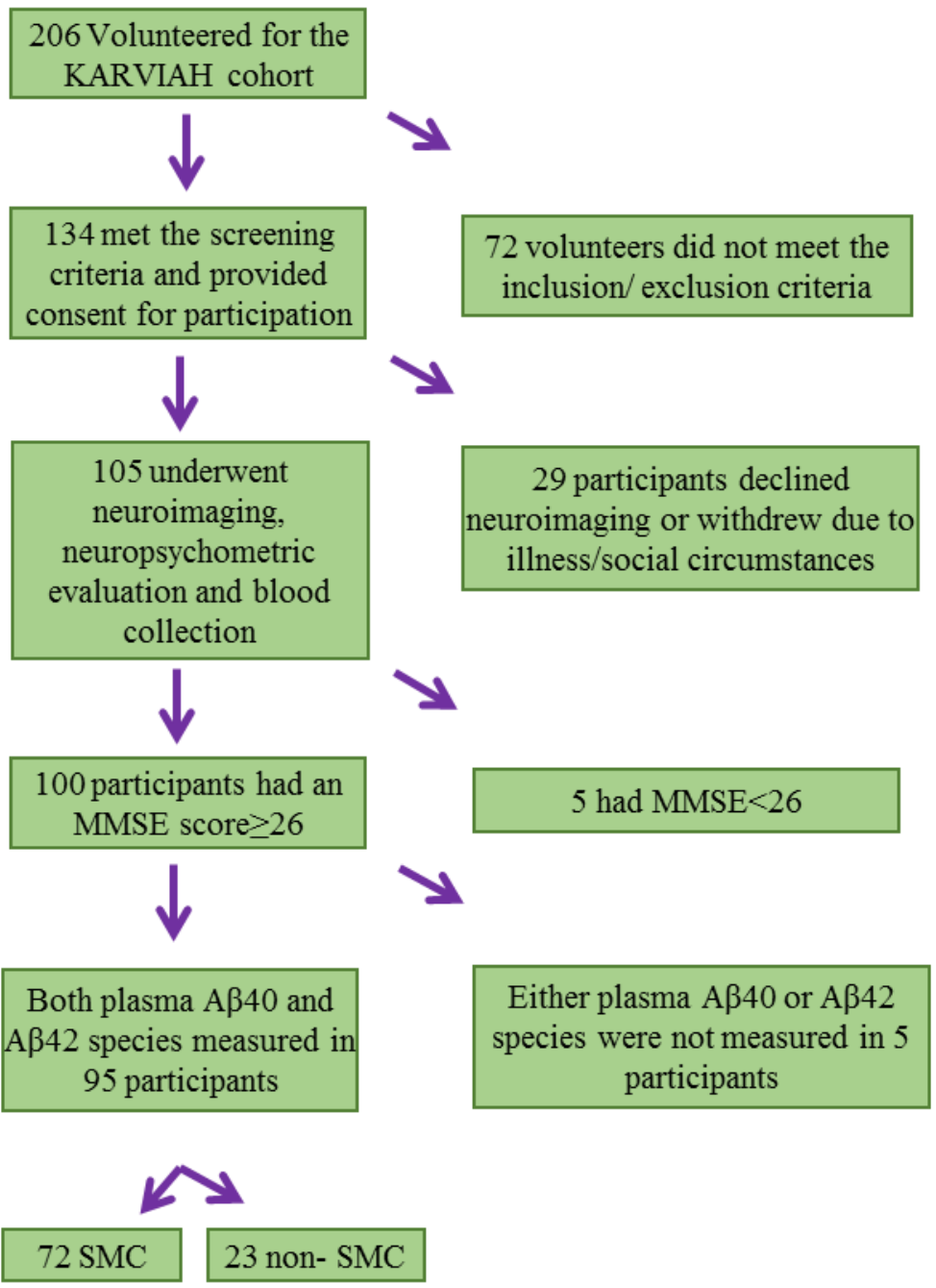




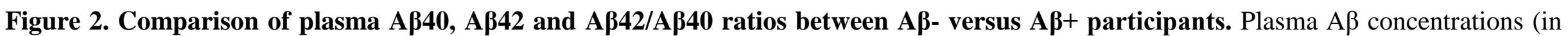
$\mathrm{pg} / \mathrm{mL}$ ) and their ratios were compared between participants with neocortical amyloid- $\beta$ load (assessed by the standard uptake value ratio observed via positron emission tomography using ligand ${ }^{18} \mathrm{~F}$-florbetaben) $<1.35(\mathrm{~A} \beta-)$ and $\geq 1.35(\mathrm{~A} \beta+)$ using linear models. Plasma $\mathrm{A} \beta 42 / \mathrm{A} \beta 40$ ratios were significantly lower in $A \beta+(N=32)$ participants compared to $A \beta-(N=63)$ participants. The line segment within each jitter plot represents the median of the data and error bars in the graphs represent the data range for the $A \beta$ - and $A \beta+$ groups. $P$-values were obtained from log transformed plasma $\mathrm{A} \beta$ concentrations and ratios to better approximate normality and variance homogeneity when required. ${ }^{*} \mathrm{p}<.005$.
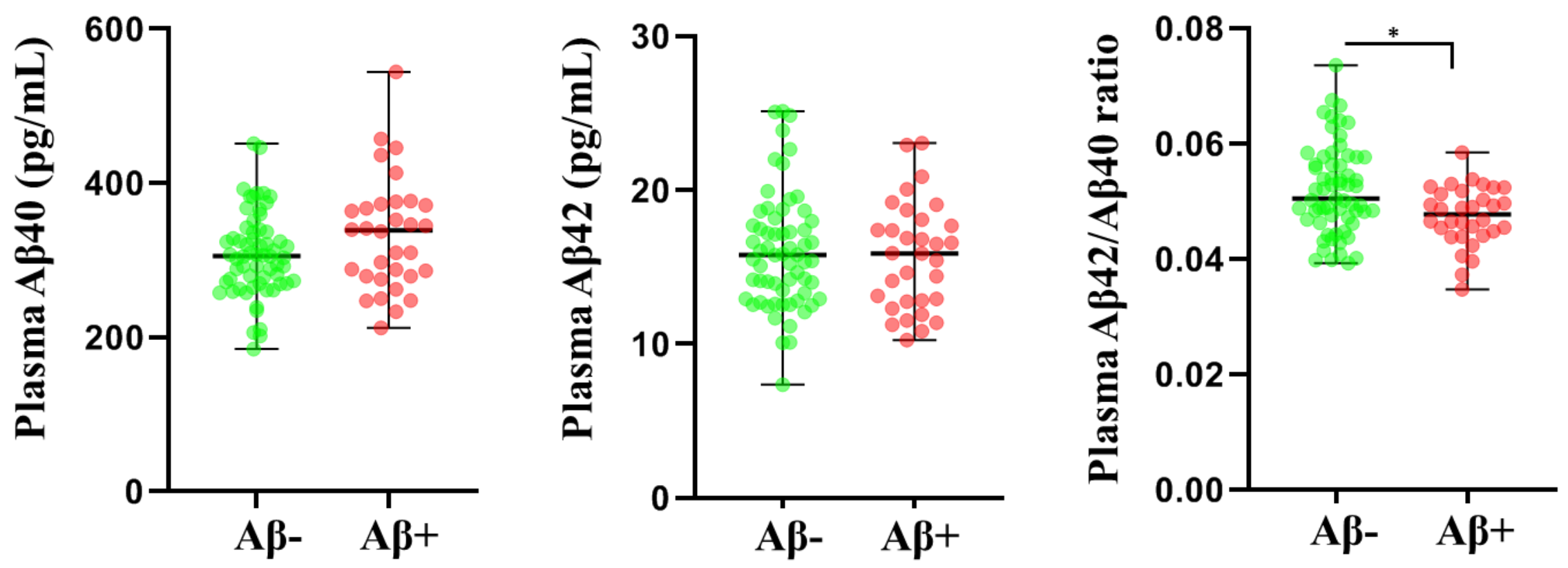
Figure 3. Receiver operating characteristic curves for the prediction of $A \beta+$ versus $A \beta$ participants. The 'base' model comprising major risk factors age and APOE \&4 allele status (A) was outperformed by the 'base + plasma A $\beta 42 / \mathrm{A} \beta 40$ ratio' model (B). Logistic regression models were employed to perform the analyses. AUC: area under the curve. $95 \% \mathrm{CI}$ for $\mathrm{A}=$ $65-86 \%, 95 \%$ CI for $\mathrm{B}=68-88 \%$.

A. Base model

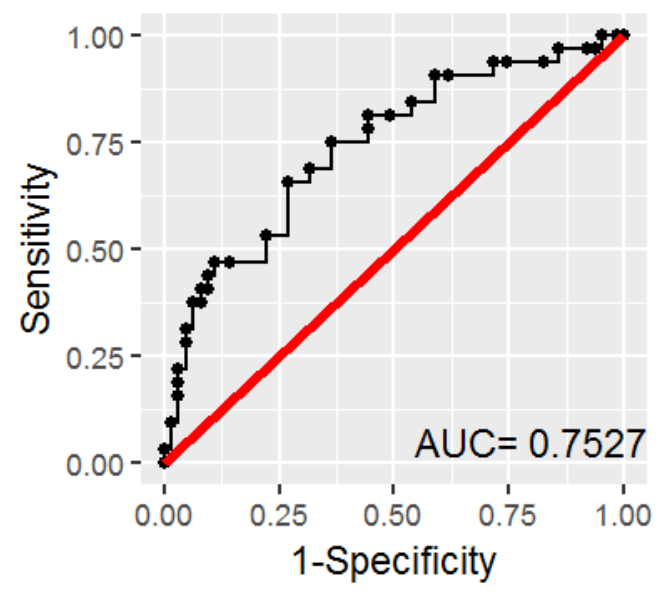

B. Base model $+\mathrm{A} \beta 42 / \mathrm{A} \beta 40$ ratio

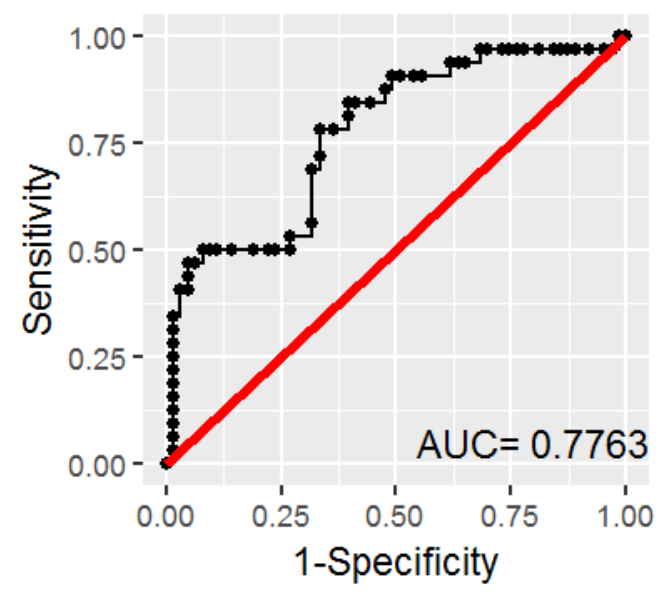




\section{Supplementary material}

Supplementary figure 1. Comparison of plasma $A \beta 40 / A \beta 42$ ratios between $A \beta$ - versus A $\beta+$ participants. Plasma $A \beta 40 / A \beta 42$ ratios were compared between participants with neocortical amyloid- $\beta$ load (assessed by the standard uptake value ratio observed via positron emission tomography using ligand ${ }^{18} \mathrm{~F}$-florbetaben) $<1.35(\mathrm{~A} \beta-)$ and $\geq 1.35(\mathrm{~A} \beta+)$ using linear models. Plasma $A \beta 40 / A \beta 42$ ratios were significantly higher $A \beta+(N=32)$ participants compared to $A \beta$ - $(\mathrm{N}=63)$ participants. The line segment within each jitter plot represents the median of the data and error bars in the graphs represent the data range for the $A \beta$ - and $A \beta+$ groups. The p-value was obtained from the log transformed values of plasma $A \beta 40 / A \beta 42$ ratios to better approximate normality and variance homogeneity. $* \mathrm{p}<.005$.

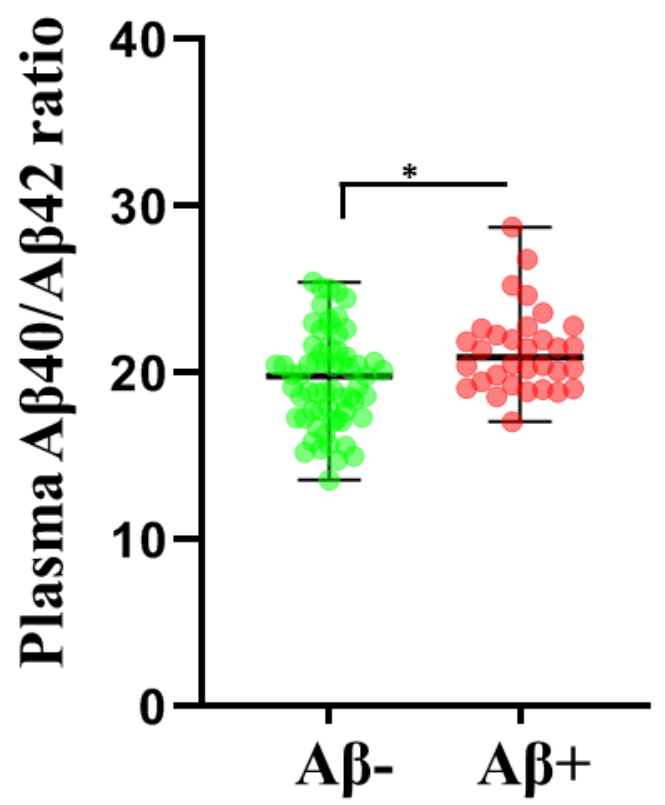


Supplementary figure 2. Receiver operating characteristic (ROC) curves for the prediction of A $\boldsymbol{\beta}+$ versus A $\boldsymbol{\beta}$ - participants. The 'base' model comprising major risk factors age and $A P O E \& 4$ allele status (A) was outperformed by the 'base + plasma A $\beta 40 / \mathrm{A} \beta 42$ ratio' model (B). Logistic regression models were employed to perform the analyses. AUC: area under the curve. $95 \% \mathrm{CI}$ for $\mathrm{A}=65-86 \%, 95 \% \mathrm{CI}$ for $\mathrm{B}=68-88 \%$

A. Base model

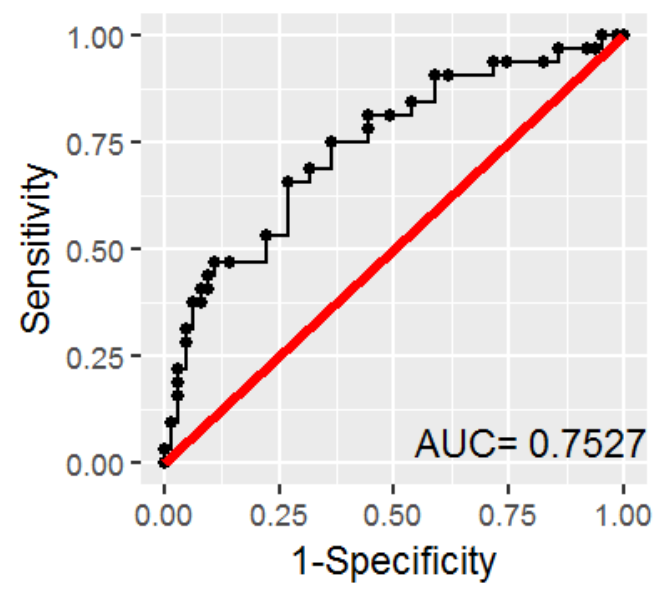

B. Base model $+\mathrm{A} \beta 40 / \mathrm{A} \beta 42$ ratio

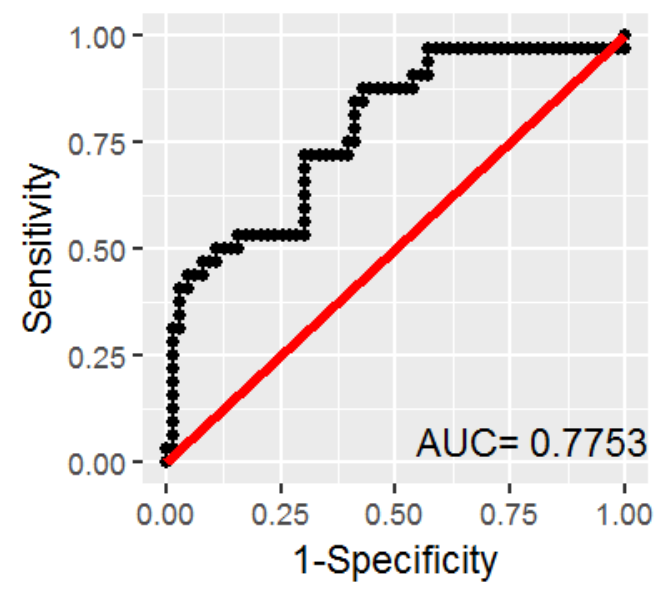


Supplementary table 1: Comparison of studies that investigated plasma A $\beta$ ratios between individuals with low (A $\beta$-) and high (A $\beta+$ ) brain $A \beta$ burden described within the current manuscript text.

\begin{tabular}{|c|c|c|c|c|}
\hline Author & $\begin{array}{l}\text { Technology } \\
\text { used }\end{array}$ & $\begin{array}{l}\text { Clinical classification } \\
\text { of participants within } \\
\text { the } A \beta-/+ \text { groups }\end{array}$ & $\begin{array}{l}\text { Brain A } \beta \\
\text { burden }(\mathrm{A} \beta-/+) \\
\text { assessed by } \\
\text { PET or CSF }\end{array}$ & Findings reported on plasma $A \beta$ ratios between $A \beta-/+$ individuals \\
\hline $\begin{array}{l}\text { Ovod et. } \\
\text { al., } 2017\end{array}$ & IP-MS & $\mathrm{CN}, \mathrm{MCI}, \mathrm{AD}$ & PET & $\begin{array}{l}\text { - Lower plasma } A \beta 42 / A \beta 40 \text { ratios in } A \beta+\text { participants versus } A \beta \text { - participants. } \\
\text { - Plasma } A \beta 42 / A \beta 40 \text { ratios distinguished between } A \beta+\text { and } A \beta \text { - participants } \\
\text { with } \sim 88 \% \text { accuracy }\end{array}$ \\
\hline $\begin{array}{l}\text { Nakamura } \\
\text { et. al., } \\
2018\end{array}$ & IP-MS & CN, MCI, AD & PET & $\begin{array}{l}\text { - Higher plasma } A \beta 40 / A \beta 42 \text { ratios in } A \beta+\text { participants versus } A \beta \text { - participants. } \\
\text { - Composite scores obtained from } A \beta 1-40 / A \beta 1-42 \text { ratio and } A P P 669-711 / A \beta 1- \\
42 \text { ratio distinguished between } A \beta+\text { and } A \beta \text { - participants with over } 90 \% \\
\text { accuracy in discovery and validation cohorts }\end{array}$ \\
\hline $\begin{array}{l}\text { Jandalidze } \\
\text { et. al., } \\
2016\end{array}$ & Simoa & $\begin{array}{l}\text { Non-SCD-CN, SCD- } \\
\text { CN, MCI, AD }\end{array}$ & PET & $\begin{array}{l}\text { - Inverse correlations between brain } A \beta \text { load and plasma } A \beta 42 / A \beta 40 \text { ratio in } \\
\text { the all participants within the study } \\
\text { - Plasma } A \beta 42 / A \beta 40 \text { ratio correlated with brain } A \beta \text { load in the } S C D-C N \text { group, } \\
\text { but not in non-SCD-CN and MCI }\end{array}$ \\
\hline $\begin{array}{l}\text { Fandos et. } \\
\text { al., } 2017\end{array}$ & ELISA & $\mathrm{CN}$ & PET & $\begin{array}{l}\text { - Lower plasma } \mathrm{A} \beta 42 / \mathrm{A} \beta 40 \text { ratios in } \mathrm{A} \beta+\text { participants versus } \mathrm{A} \beta \text { - participants. } \\
\text { - Plasma } \mathrm{A} \beta 42 / \mathrm{A} \beta 40 \text { ratios, along with risk factors, age and } A P O E \varepsilon 4 \text { status, } \\
\text { distinguished between } \mathrm{A} \beta+\text { and } \mathrm{A} \beta \text { - participants with } \sim 79 \% \text { accuracy, based } \\
\text { on the AUC under the ROC curve }\end{array}$ \\
\hline $\begin{array}{l}\text { Verberk } \\
\text { et. al., } \\
2018\end{array}$ & Simoa & $\mathrm{SCD}-\mathrm{CN}$ & CSF & $\begin{array}{l}\text { - Lower plasma } \mathrm{A} \beta 42 / \mathrm{A} \beta 40 \text { ratios in } \mathrm{A} \beta+\text { participants versus } \mathrm{A} \beta \text { - participants. } \\
\text { - Plasma } \mathrm{A} \beta 42 / \mathrm{A} \beta 40 \text { ratios, along with risk factors, age and } A P O E \varepsilon 4 \text { status, } \\
\text { distinguished between } \mathrm{A} \beta+\text { and } \mathrm{A} \beta \text { - participants with } \sim 83 \% \text { accuracy, based } \\
\text { on the AUC under the ROC curve }\end{array}$ \\
\hline $\begin{array}{l}\text { Current } \\
\text { study }\end{array}$ & Simoa & $\begin{array}{l}\mathrm{CN} \text { (non-SMC-CN and } \\
\text { SMC-CN combined, as } \\
\text { well as in non-SMC-CN } \\
\text { and } \quad \text { SMC-CN } \\
\text { independently stratified) }\end{array}$ & PET & $\begin{array}{l}\text { - Lower plasma } A \beta 42 / A \beta 40 \text { (higher } A \beta 40 / A \beta 42 \text { ) ratios in } A \beta+\text { participants } \\
\text { versus } A \beta \text { - participants. } \\
\text { - Plasma } A \beta 42 / A \beta 40 \text { ratios, along with risk factors, age and } A P O E \varepsilon 4 \text { status } \\
\text { distinguished between } A \beta+\text { and } A \beta \text { - participants with } ~ 78 \% \text { accuracy, based } \\
\text { on the area under the ROC curve in all participants. }\end{array}$ \\
\hline
\end{tabular}


